\title{
RADIOLYTIC GAS PRODUCTION FROM TRITIATED WASTE FORMS
}

GAMMA AND ALPHA RADIOLYSIS STUDIES

NED E. BIBLER

ERROL G. OREBAUGH

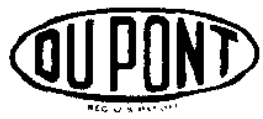

SAVANNAH RIVER LABORATORY AIKEN, SOUTH CAROLINA 29801 


\section{NOTICE}

This report was prepared ss an account of work sponsored by the United States Government. Neither the United States nor the United States Energy Research and Devalopment Administration, nor any of their contractors, subcontractors, or their employees, makes any warranty, express or implied, or assumes any legal liability or responsibility for the accuracy, completeness or usefuiness of ony information, apparatus. product or process disclosed, or represents that its use would not infringe privately owned rights.

Printed in the United States of America

Available from

National Technical information Service

U.S. Department of Commerce

5285 Port Royal Road

Springfield, Virginia 22161

Price: Printed Copy $\$ 4.00 ;$ Microfiche $\$ 3.00$ 


\section{RADIOLYTIC GAS PRODUCTION FROM TRITIATED WASTE FORMS}

GAMMA AND ALPHA RADIOLYSIS STUDIES

by

Ned E. Bibler

Errol G. Orebaugh

Approved by

M. L. Hyder, Research Manager

Separations Chemistry Division

Publication Date: July 1977

\section{E. I. DU PONT DE NEMOURS AND COMPANY SAVANNAH RIVER LABORATORY AIKEN, SOUTH CAROLINA 29801}


Radiolytic gas production during long-term storage of tritiated waste was estimated from gamma and alpha radiolysis tests to determine the extent of pressurization in sealed containers. Two forms of simulated wastes were irradiated with ${ }^{60} \mathrm{Co}$ gamma rays or ${ }^{244} \mathrm{Cm}$ alpha particles: concrete for solidification of tritiated water and vermiculite for solidification of tritiated octane or vacuum pump oil. Results of these test irradiations were used to estimate the effects of beta radiolysis. For concrete, the gamma and alpha radiolysis results predicted that $\mathrm{H}_{2}$ will be formed by tritium beta particles with an initial rate of 0.1 to 0.3 molecule for every $100 \mathrm{eV}$ of energy absorbed. Also, as the $\mathrm{H}_{2}$ pressure increases, this $100-\mathrm{eV}$ yield decreases because of a reaction removing $\mathrm{H}_{2}$. Eventually, a steady state pressure that depends on the radiation intensity will be attained. For intensities less than $10^{5} \mathrm{rads} / \mathrm{hr}$, the steady state pressure will be less than 20 psi. $\mathrm{O}_{2}$ in the air sealed with the concrete will be almost completely depleted, and $\mathrm{N}_{2}$ will be unaffected. For the organic materials sorbed onto vermiculite, the gamma and alpha radiolysis results predicted that $\mathrm{H}_{2}$ and traces of $\mathrm{CH}_{4}$ and $\mathrm{CO}_{2}$ will be produced. For tritium beta particles, the $100-\mathrm{eV}$ yields for $\mathrm{H}_{2}$ based on energy sorbed by the organic materials are 4.4 for octane and 2.2 for vacuum pump oil. In the containers, steady state $\mathrm{H}_{2}$ pressure will not be attained at pressures up to at least $200 \mathrm{psi}$. As with the concrete, $\mathrm{O}_{2}$ will be nearly completely depleted and $\mathrm{N}_{2}$ will be unaffected. The $100-\mathrm{eV}$ yield for $\mathrm{H}_{2}$ production was used to calculate pressure increases in conceptual tritiated waste packages. 


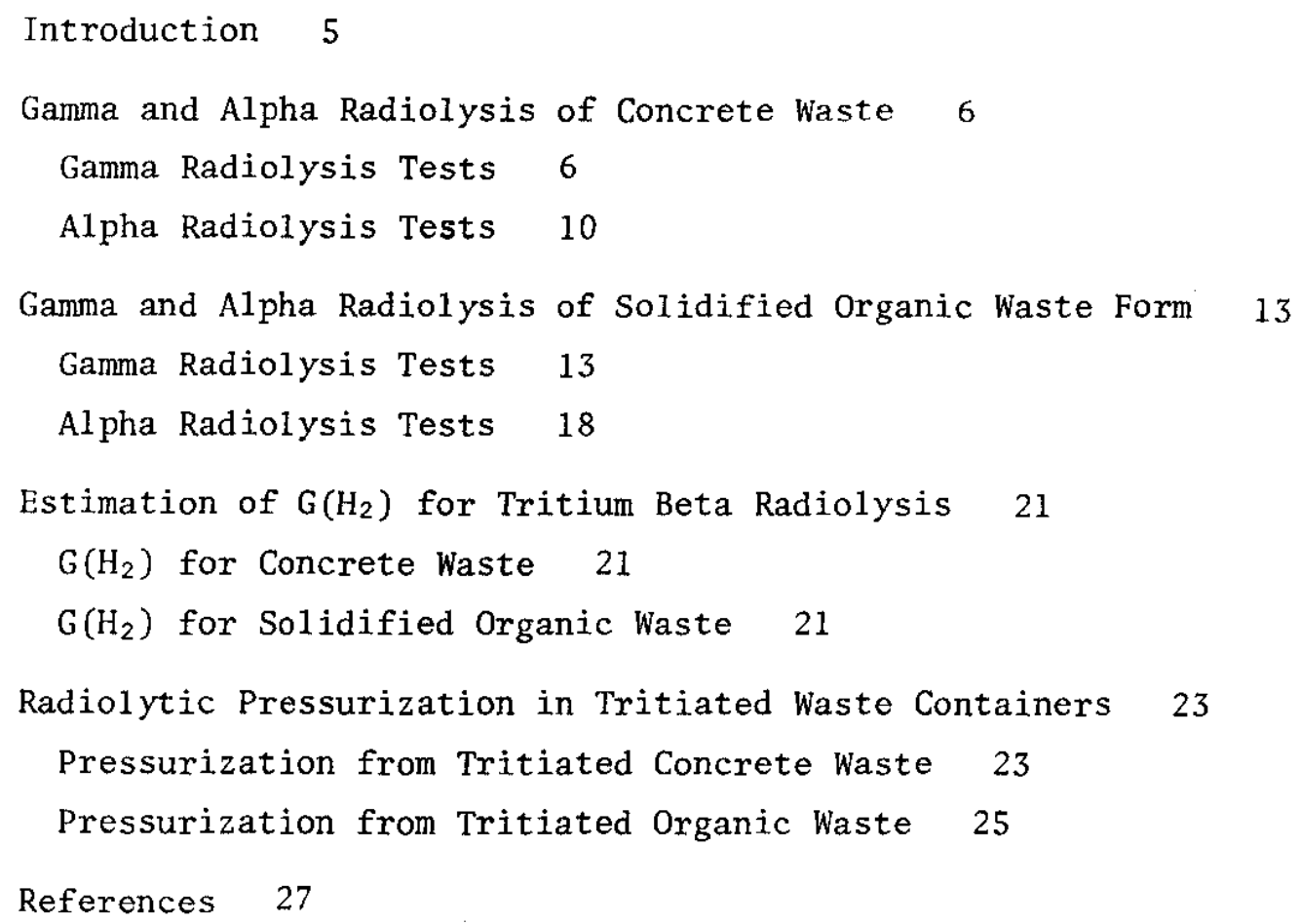




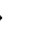




\section{RADIOLYTIC GAS PRODUCTION FROM TRITIATED WASTE FORMS}

GAMMA AND ALPHA RADIOLYSIS STUDIES

\section{INTRODUCTION}

Various types of waste materials containing tritium, ${ }^{3} \mathrm{H}$, from nuclear processing facilities are incorporated into solid materials and packaged for long-term storage and isolation from the environment. Current solidification methods are incorporation into cement-plaster mixtures for aqueous wastes and sorption onto vermiculite for organic wastes. ${ }^{1}$ These materials are then sealed in steel drums for storage. Other solidification methods such as incorporation into stable organic polymeric materials are a1so being investigated. ${ }^{2}$

During long-term storage of the waste, ${ }^{3} \mathrm{H}$ beta radiolysis of the water or organic materials will produce $\mathrm{H}_{2}$ gas. $\mathrm{H}_{2}$ could eventually pressurize the containers or produce flammable gaseous mixtures. Although the radiolysis of water and of many organic compounds has been extensively studied in the pure state, 3,4 materials have not been irradiated in matrices suitable for storage of radioactive waste. Even though certain predictions of radiolytic gas behavior can be made from results of radiolysis of the pure compounds, the pressurization or flammability hazards during long-term storage can best be evaluated from radiolysis of the waste form itself.

This report presents an estimation of $\mathrm{H}_{2}$ production from in situ beta radiolysis of a concrete containing tritiated water and of vermiculite containing sorbed tritiated organic waste. Estimates were based on experimental data for the $100-\mathrm{eV}$ yields of $\mathrm{H}_{2}$ from ${ }^{60} \mathrm{Co}$ gamma and ${ }^{244} \mathrm{Cm}$ alpha radiolysis of the two waste forms. The estimated rate of $\mathrm{H}_{2}$ for ${ }^{3} \mathrm{H}$ beta radiolysis was interpolated from the rates of gamma and alpha radiolysis as a function of linear energy transfer (LET) of the three radiations. LET, the average amount of energy lost per unit path length as the radiation passes through a substance, strongly affects the efficiency of radiolytic decomposition and, consequently, gas production. ${ }^{5}$ The LET values for ${ }^{60} \mathrm{Co}$ gamma and ${ }^{244} \mathrm{Cm}$ alpha radiolysis bracket that of ${ }^{3} \mathrm{H}$ beta radiolysis. ${ }^{5}$ Once the $100-\mathrm{eV}$ yield for $\mathrm{H}_{2}$ production for ${ }^{3} \mathrm{H}$ beta radiolysis was estimated, this value was used to calculate pressure increases in containers of tritiated waste. 
This approach was chosen rather than using ${ }^{3} \mathrm{H}$ as the radiation source because this laboratory is especially suited for gamma and alpha radiolysis studies. For gamma radiolysis, many experiments could be performed over a wide dose and dose rate range with any of four ${ }^{60} \mathrm{Co}$ sources. For alpha radiolysis, sufficient ${ }^{244} \mathrm{Cm}$ was available along with facilities for easily performing several such experiments.

Samples of concrete or vermiculite containing sorbed organic material were irradiated. These samples were sealed in steel containers that had attached pressure gauges and sampling valves. During radiolysis, the pressure was monitored; after radiolysis, the gas was sampled and its composition was determined by gas chromatography.

\section{GAMMA AND ALPHA RADIOLYSIS OF CONCRETE WASTE}

A mixture of portland cement and gypsum-perlite plaster is currently used for solidification of tritiated aqueous waste. ${ }^{1}$ The waste water is mixed with the dry cement-plaster powder in the ratio of nominally $1: 1.7$ by volume or $1: 1.4$ by weight with $0.8 \mathrm{~g} / \mathrm{mL}$ as the bulk density of the dry material. For the gamma radiolysis tests, the concrete was cast in a glass container with an attached pressure gauge and sampling valve. The pressure gauge and sampling valve were separated from the irradiation container by several feet of 1/8-inch-ID steel tubing. The alpha radiolysis tests were performed in glove boxes. The ${ }^{244} \mathrm{Cm}$ was dissolved in the water used to make the concrete, thus ensuring that ${ }^{244} \mathrm{Cm}$ was in direct contact with the compounds of the concrete. Each concrete sample was cast in a steel tube that was then sealed to a pressure gauge and sampling valve.

\section{Gamma Radiolysis Tests}

The gamma radiolysis tests determined the effects of dose rate and total dose on the rate of $\mathrm{H}_{2}$ production. Results of these tests indicated that the initial rate of $\mathrm{H}_{2}$ production was proportional to dose rate. However, in terms of molecules produced per $100 \mathrm{eV}$ of energy absorbed ( $G$ value), the rate was independent of dose rate and was 0.03 molecule/100 eV from $8.9 \times 10^{4}$ to $2.6 \times 10^{7} \mathrm{rads} / \mathrm{hr}$. As the radiation dose increased and consequently the $\mathrm{H}_{2}$ pressure increased, the $\mathrm{H}_{2}$ pressurization rate decreased until eventually a steady state pressure was attained. This indicates the occurrence of a radiolytic back reaction removing $\mathrm{H}_{2}$. The magnitude of this steady state pressure decreased with the dose rate. This behavior has also been observed in gamma radiolysis of another type of concrete containing simulated fission product wastes. ${ }^{6}$ In these gamma radiolysis tests, $\mathrm{O}_{2}$ in the air sealed in the container was partially consumed and $\mathrm{N}_{2}$ was unaffected. 


\section{Results and Discussion}

Radiolytic pressure increases for two samples of concrete irradiated in containers of nearly equal free volumes are shown in Figure 1. The attainment of steady state pressures that are dependent on dose rate is clearly indicated. Gas composition at the end of the tests was $70 \% \mathrm{H}_{2}, 27 \% \mathrm{~N}_{2}$, and $3 \% \mathrm{O}_{2}$. Comparison of the individual partial pressures before and after radiolysis confirmed that $\mathrm{H}_{2}$ was the only gas produced, $\mathrm{Also}, \mathrm{N}_{2}$ was unaffected by the radiolysis, and $\mathrm{O}_{2}$ was $275 \%$ consumed. $\mathrm{O}_{2}$ consumption has also been observed in radiolysis of the concrete containing simulated fission product waste. ${ }^{6}$ Data in Figure 1 also indicate that the initial $\mathrm{H}_{2}$ production rate is higher at the higher radiation intensity. However, when based on the amount of energy absorbed, the production rates were equal.

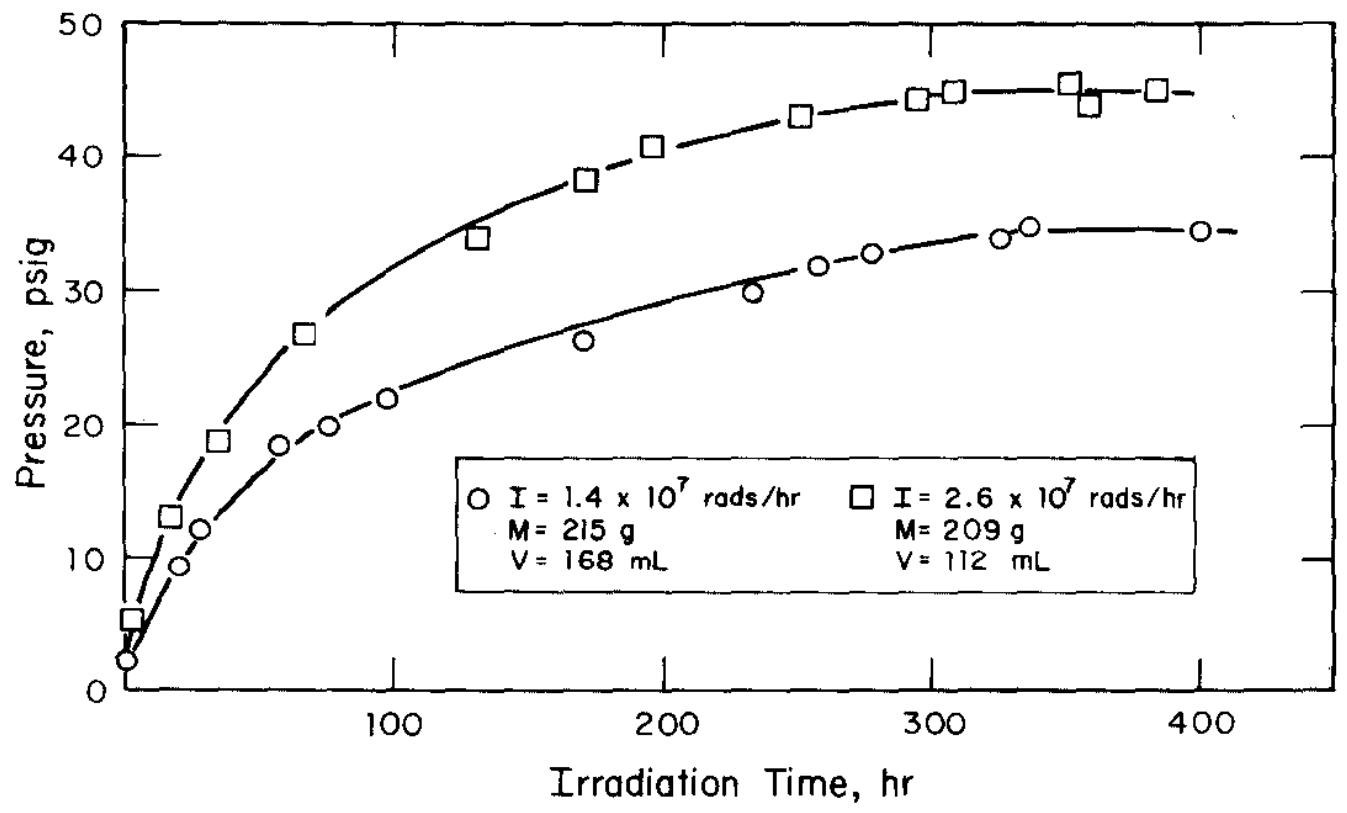

FIGURE 1. Pressurization from Gamma Radiolysis of Concrete at $47^{\circ} \mathrm{C}$ 


$$
\mathrm{G}\left(\mathrm{H}_{2}\right)=\frac{\mathrm{S} \cdot \mathrm{V} \cdot \mathrm{N} \cdot 100}{\mathrm{R} \cdot \mathrm{T} \cdot \mathrm{M} \cdot \mathrm{I} \cdot \mathrm{C}}
$$

where

$$
\begin{aligned}
& \mathrm{S}=\text { initial slope, psi/hr } \\
& \mathrm{V}=\text { gas volume, liter } \\
& \mathrm{N}=\text { Avogadro's number, molecules/mole } \\
& \mathrm{R}=\text { gas constant, psi }(1 \mathrm{iter} / \mathrm{mole})\left({ }^{\circ} \mathrm{K}\right) \\
& \mathrm{T}=\text { temperature, }{ }^{\circ} \mathrm{K} \\
& \mathrm{M}=\text { mass of cement irradiated, } \mathrm{g} \\
& \mathrm{I}=\text { dose rate, rads/hr } \\
& \mathrm{C}=\text { conversion factor, } 6.24 \times 10^{13} \mathrm{eV}(\mathrm{g})(\mathrm{rad})
\end{aligned}
$$

For both samples, $\mathrm{G}\left(\mathrm{H}_{2}\right)$ was $0.03 \pm 0.01$ molecule/100 eV.

To determine the radiation intensity dependence of the steady state pressure over a wider dose rate range, samples were irradiated at two lower dose rates $\left(3.9 \times 10^{5}\right.$ and $8.9 \times 10^{4}$ $\mathrm{rads} / \mathrm{hr})$. At these dose rates, irradiating the samples was impractical. Thus, the sample containers were back-pressurized with $\mathrm{H}_{2}$ until radiolytic $\mathrm{H}_{2}$ pressurization ceased. Results for a11 four dose rates are shown in Figure 2; the error bars indicate the reproducibility of the tests. This attainment of a steady state pressure and its dose rate dependence are consistent with the free radical mode 1 for $\mathrm{H}_{2}$ production from gamma radiolysis of water. ${ }^{3}$ The oxide components of the cement and plaster are not drastically altering the radiation chemistry of the water. In the free radical model, $\mathrm{H}_{2}$ is formed by recombination of $\mathrm{H}$ atoms produced by the radiation and destroyed by $\mathrm{OH}$ radicals, the other major species produced by radiolysis of water. Pertinent reactions are

$$
\begin{aligned}
& \mathrm{H}_{2} \mathrm{O} \rightarrow \mathrm{H}+\mathrm{OH} \\
& \mathrm{H}+\mathrm{H} \rightarrow \mathrm{H}_{2} \\
& \mathrm{OH}+\mathrm{H}_{2} \rightarrow \mathrm{H}_{2} \mathrm{O}+\mathrm{H}
\end{aligned}
$$




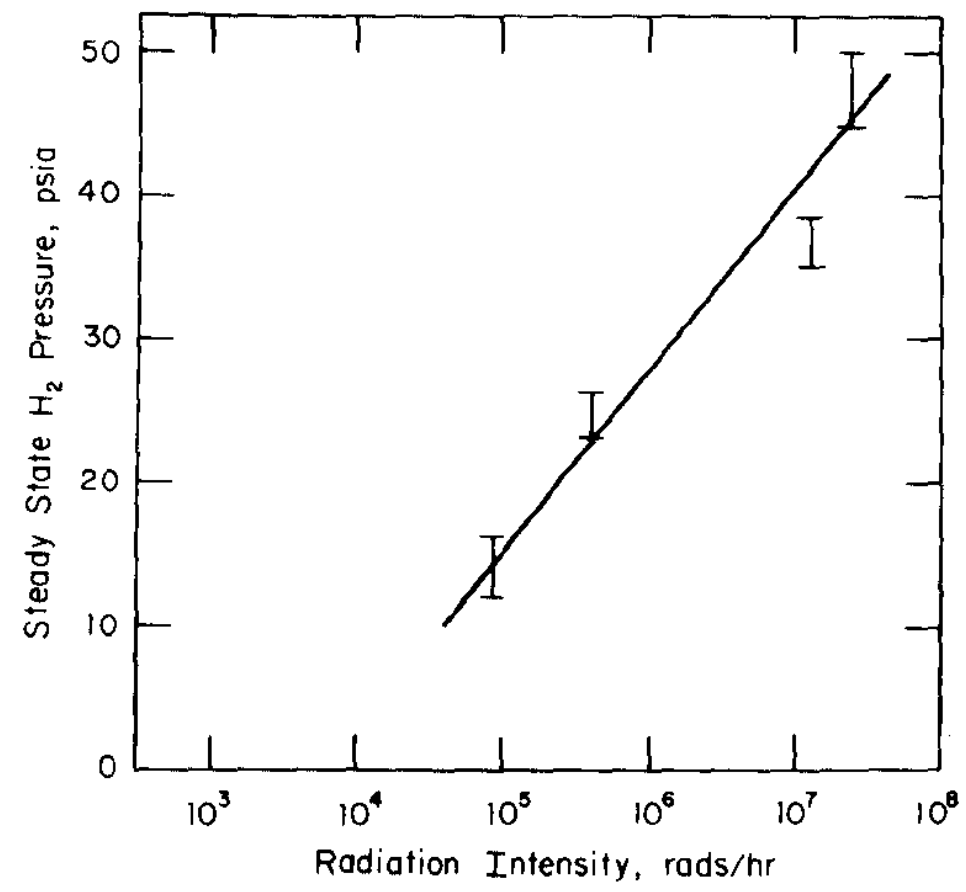

FIGURE 2. Effect of Dose Rate on Steady State $\mathrm{H}_{2}$ Pressure from Gamma Radiolys is of Concrete

When the rates of Reactions 3 and 4 become equal, a steady state $\mathrm{H}_{2}$ pressure is attained. Higher dose rates increase the rates of both 3 and 4 but increase 3 faster because 3 involves two radicals. ${ }^{7}$ Thus, at higher dose rates, higher $\mathrm{H}_{2}$ pressures are necessary to compensate for the larger increase in the rate of 3 .

Tests at $8.9 \times 10^{4}$ and $3.9 \times 10^{5} \mathrm{rads} / \mathrm{hr}$ agreed with those obtained at the higher dose rates. $\mathrm{G}\left(\mathrm{H}_{2}\right)$ was $0.03, \mathrm{O}_{2}$ was partially consumed, and $\mathrm{N}_{2}$ was unaffected. The steady state $\mathrm{H}_{2}$ pressure was independent of the gas volume. This pressure was al so observed in gamma radiolysis of concrete containing simulated fission product waste. ${ }^{6}$ Identical pressurization rates were obtained at the same dose rate whether the concrete sample was cured 1 or 20 days. Results were also identical within water: cement-plaster volume ratios of $1: 1.7$ to $1: 4.3$ ( $1: 1.3$ to $1: 3.4$ by weight) with $0.8 \mathrm{~g} / \mathrm{mL}$ as the bulk density of the dry material.

A final gamma radiolysis test determined the extent of $\mathrm{O}_{2}$ depletion from the air sealed with the concrete. In previous tests, the entire gas was removed from the sealed system for analysis because earlier results had shown that incomplete mixing occurred during radiolysis due to the small tubing connecting the irradiation container to the pressure gauge and sampling valve. In absence of these latter components, $95 \%$ of the $\mathrm{O}_{2}$ was consumed rather than $275 \%$ as found earlier. Another 
study $^{6}$ determined that this consumption may be due to $\mathrm{H}$ atoms reacting with $\mathrm{O}_{2}$ to eventually form $\mathrm{H}_{2} \mathrm{O}_{2}$ :

$$
\begin{aligned}
& \mathrm{H}+\mathrm{O}_{2} \rightarrow \mathrm{HO}_{2} \\
& 2 \mathrm{HO}_{2} \rightarrow \mathrm{H}_{2} \mathrm{O}_{2}+\mathrm{O}_{2}
\end{aligned}
$$

These reactions also occur in radiolysis of 1 iquid water containing $\mathrm{O}_{2}{ }^{3}$

\section{Experimental Procedures}

For the tests at dose rates of $1.4 \times 10^{7}$ and $2.6 \times 10^{7}$ $\mathrm{rads} / \mathrm{hr}$, samples were irradiated with a $\sim 1-\mathrm{MCi}{ }^{60} \mathrm{Co}$ source submerged in $\sim 20 \mathrm{ft}$ of water. Concrete samples were poured into $3.8-\mathrm{cm}-$ ID $\times 19-\mathrm{cm}-1$ long glass tubes closed at one end, and allowed to cure at least 1 day. The tube and sample were then sealed in a tightly fitting steel container attached to a pressure gauge and sampling valve by $\sim 25 \mathrm{ft}$ of $\sim 0.1-\mathrm{cm}$-ID tubing. Nominally $200 \mathrm{~g}$ of concrete was irradiated. The average dose rate received by the concrete was determined by $1-\mathrm{cm}^{2}$ thin-film dosimeters, ${ }^{8}$ calibrated against the standard Fricke dosimeter. ${ }^{9}$ Because of the large volume of the concrete samples, the film dosimeters were irradiated in holes drilled in the center and on the outer edge of the concrete sample. The average of these results was then used as the dose rate. The volume in the system (with the concrete sample present) available to gas was determined by expanding a known volume of gas at a known pressure into the system and measuring the pressure decrease. Tests at $8.9 \times 10^{4}$ and $3.9 \times 10^{5} \mathrm{rads} / \mathrm{hr}$ were performed in a Gammacell $220^{*}{ }^{60} \mathrm{Co}$ source. Samples were cast and irradiated in $500-\mathrm{cc}$ bottles connected to a pressure gauge and sampling valve by $\sim 6$ $\mathrm{ft}$ of $20.1-\mathrm{cm}-\mathrm{ID}$ tubing. Nominally, $1 \mathrm{~kg}$ of concrete was irradiated. The average dose rate to the concrete was determined by the standard Fricke dosimeter. As with the high dose rate determinations, the dose rate was the average of dosimeters placed at the center and outer edge of the concrete. Gas volume was determined as in the high dose rate tests.

\section{Alpha Radiolys is Tests}

To determine $\mathrm{G}\left(\mathrm{H}_{2}\right)$ for alpha radiolysis, concrete samples containing various amounts of $244 \mathrm{Cm}$ were prepared in a glove box and sealed in steel containers with attached pressure gauges

* Atomic Energy of Canada, Ltd., Ottawa, Canada. 
and sampling valves. The range of the alpha particles in the concrete is $20.01 \mathrm{~mm}$; thus, a11 the alpha energy was absorbed by the sample. For four tests with $11.5 \mathrm{~g}$ of concrete and 0.84 to $32 \mathrm{mg}$ of ${ }^{244} \mathrm{Cm}, \mathrm{G}\left(\mathrm{H}_{2}\right)$ was independent of the amount of ${ }^{244} \mathrm{Cm}$ and was 0.6 molecule/100 eV. This value is 20 times larger than that obtained for gamma radiolysis. This increase is not unexpected because $\mathrm{G}\left(\mathrm{H}_{2}\right)$ from Iiquid water is 4 times larger for alpha than for gamma radiation. ${ }^{3}$ As with gamma radiolysis, $\mathrm{O}_{2}$ was partially consumed and $\mathrm{N}_{2}$ was unaffected. In contrast to gamma radiolysis, a steady state pressure was not attained even at $\sim 200 \mathrm{psi} \mathrm{H}_{2}$. Failure to attain a steady state pressure was also observed in another study concerning alpha radiolysis of concrete containing simulated fission product waste. ${ }^{6}$

\section{Results and Discussion}

Figure 3 shows the radiolytic pressure increase for a sample of concrete containing $0.84 \mathrm{mg}$ of ${ }^{244} \mathrm{Cm}$. At the end of this test, the gas composition was $54 \% \mathrm{~N}_{2}, 40 \% \mathrm{H}_{2}$, and $6 \% \mathrm{O}_{2}$. Comparison of partial pressure of $\mathrm{N}_{2}$ and $\mathrm{O}_{2}$ before and after radiolysis indicated that $\mathrm{N}_{2}$ was unaffected and $\mathrm{O}_{2}$ was $260 \%$ consumed. $\mathrm{G}\left(\mathrm{H}_{2}\right)$ was calculated from

$$
\mathrm{G}\left(\mathrm{H}_{2}\right)=\frac{\mathrm{S} \cdot \mathrm{V} \cdot \mathrm{N} \cdot 100}{\mathrm{R} \cdot \mathrm{T} \cdot \mathrm{I}}
$$

where all the quantities except the dose rate I are identical to those defined on page 8 for the gamma radiolysis tests. I was calculated from the amount of ${ }^{244} \mathrm{Cm}$ present, its specific activity $(80.9 \mathrm{Ci} / \mathrm{g}),{ }^{10}$ and the energy of its alpha particles $(5.8 \mathrm{MeV}) .10$ For four separate tests with $0.84,6.6,13$, and $32 \mathrm{mg}$ of ${ }^{244} \mathrm{Cm}, \mathrm{G}\left(\mathrm{H}_{2}\right)$ was $0.63 \pm 0.07$ molecule/100 eV. The dose rate for these amounts of ${ }^{244} \mathrm{Cm}$ was $7.5 \times 10^{4}$ to $2.8 \times 10^{6}$ $\mathrm{rads} / \mathrm{hr}$, and indicated, in agreement with the gamma radiolysis results, that $\mathrm{G}\left(\mathrm{H}_{2}\right)$ was independent of dose rate.

Radiolytic pressurization in another alpha radiolysis test is shown in Figure 4 . This test was made to demonstrate that steady state pressure was not attained even at 200 psi. Failure to attain a steady state pressure, as in gamma radiolysis, probably results from the different modes of energy transfer by the two radiations. Alpha particles because of their high charge $(+2)$ and mass (4 amu) lose energy much faster than gamma rays. This loss of energy creates regions where the concentrations of $H$ and $O H$ radicals are much higher than with gamma radiolysis. Radical recombination reactions such as those forming $\mathrm{H}_{2}$ are favored over such as those removing $\mathrm{H}_{2}$. Because the reaction removing $\mathrm{H}_{2}$ is not as efficient, a steady state pressure is not attained. This phenomenon also occurs in the radiolysis of 
liquid water where alpha radiolysis causes continuous $\mathrm{H}_{2}$ production, and gamma radiolysis leads to very low steady state $\mathrm{H}_{2}$ pressures. ${ }^{3}$ This similarity between $\mathrm{H}_{2}$ production from concrete and water again suggests that the metal oxides of the concrete do not significantly alter the radiation chemistry of the water even though it is incorporated in the concrete. Another similarity is the higher value of $\mathrm{G}\left(\mathrm{H}_{2}\right)$ for alpha radiolysis. This higher value in water also results from the higher radical concentrations caused by alpha particles.

FIGURE 3

Pressurization from Alpha Radiolys is of Concrete at $23^{\circ} \mathrm{C}$
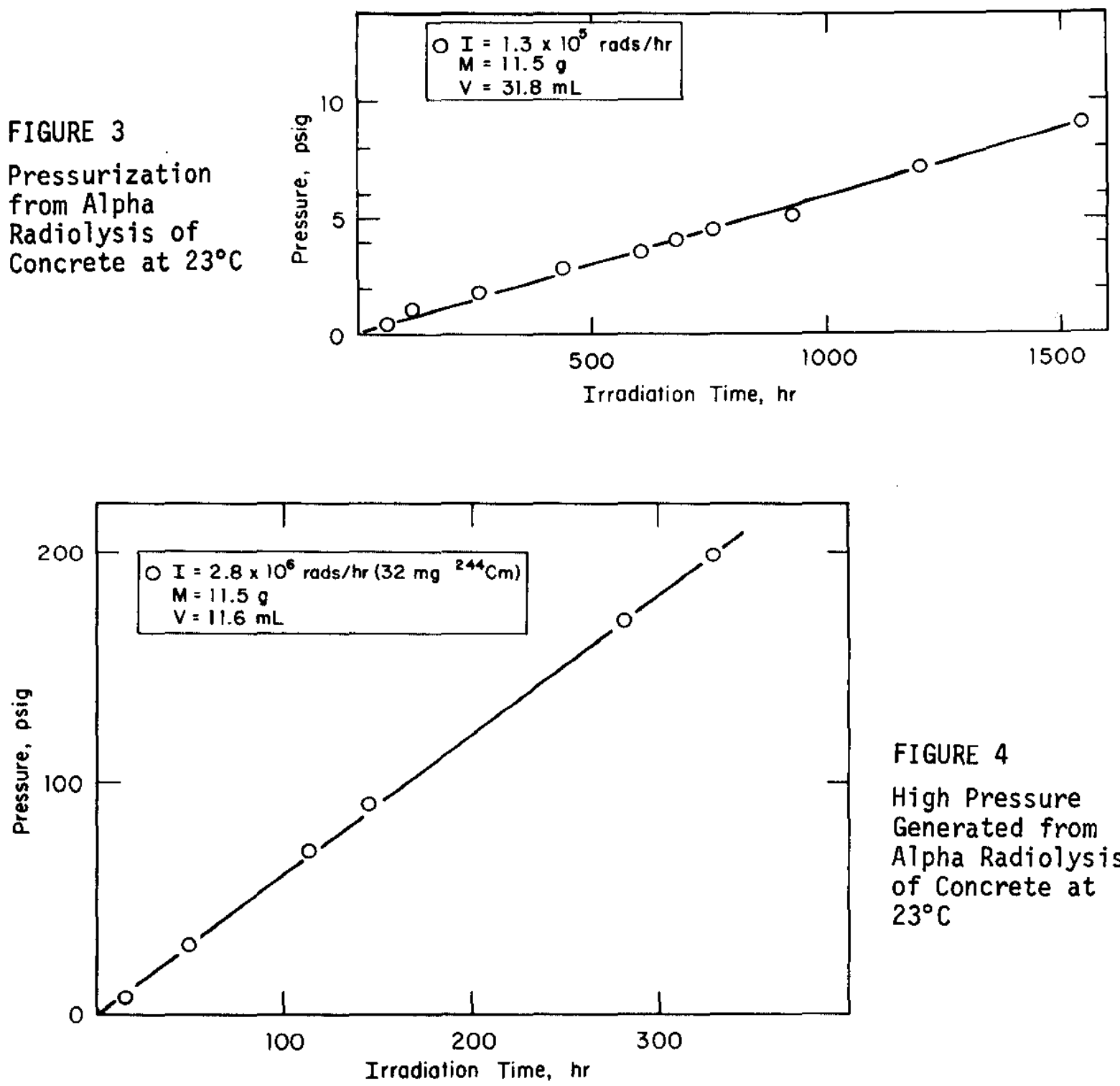

FIGURE 4

High Pressure Generated from Alpha Radiolys is of Concrete at $23^{\circ} \mathrm{C}$ 
For the radiolysis tests, $6.5 \mathrm{~g}$ of the dry cement-plaster material was mixed in a stee 1 test tube $0.9-\mathrm{cm}$ ID by $10-\mathrm{cm} 1$ ong with $5 \mathrm{~mL}$ of $0.01 \mathrm{M} \mathrm{H}_{2} \mathrm{SO}_{4}$ containing a known amount of ${ }^{244} \mathrm{Cm}$. The amount of ${ }^{244} \mathrm{Cm}$ was determined by prior absolute alpha counting an aliquot of the solution. Also, prior to mixing, $\mathrm{NO}_{3}^{-}$ions possibly present with the ${ }^{244} \mathrm{Cm}$ were destroyed by mild calcination of the ${ }^{244} \mathrm{Cn}$. ${ }^{244} \mathrm{Cm}$ was redissolved with $0.01 \mathrm{M} \mathrm{H}_{2} \mathrm{SO}_{4}$ because alpha radiolysis of $\mathrm{NO}_{3}^{-}$ions produces $\mathrm{O}_{2},{ }^{1}{ }^{1}$ which might have led to additional pressurization from the concrete. After the concrete had cured for at least 16 hours, the tube was sealed to a pressure gauge and sampling valve. After the experiment, essentially all the gas was expanded into an evacuated sampler that was then removed from the glove box. The gas was analyzed by gas chromatography. The gas volume in the system containing the concrete was determined as in the gamma radiolysis tests.

\section{GAMMA AND ALPHA RADIOLYSIS OF SOLIDIFIED ORGANIC WASTE FORM}

The organic waste form irradiated was organic materials sorbed onto vermiculite. Vermiculite, a porous, highly absorptive mineral (hydrated magnesium-aluminum-iron silicate) is currently used for solidification of organic vacuum pump oils or organic cleaning solvent contaminated with tritium. ${ }^{1}$ For this study, Duo Seal* vacuum pump oil and research-grade n-octane were used. Usually, $2.5 \mathrm{~mL}$ of the organic material was sorbed onto each gram of vermiculite. For gamma radiolysis, the mixture was sealed in a steel irradiation container connected to a pressure gauge and sampling valve as in the concrete radiolysis tests. In the alpha radiolysis tests, ${ }^{244} \mathrm{Cm}$, as an aqueous sulfate solution, was sorbed onto the vermiculite. The water was then evaporated by heating the vermiculite, and the organic material was added. This ensured that the ${ }^{244} \mathrm{Cm}$ was in direct contact with the vermiculite and organic material. The mixture was placed in a steel tube that was sealed to a pressure gauge and sampling valve.

\section{Gamma Radiolysis Tests}

Gamma radiolysis tests indicated that $\mathrm{H}_{2}$ and small amounts of $\mathrm{CO}_{2}$ and $\mathrm{CH}_{4}$ were produced, $\mathrm{N}_{2}$ was unaffected, and $\mathrm{O}_{2}$ was consumed. In contrast to gamma radiolysis of concrete, steady state $\mathrm{H}_{2}$ pressure was not attained. Also, the results indicated that only energy sorbed by the organic material produced $\mathrm{H}_{2}$. Energy sorbed by the vermiculite was not transferred to the organic material to produce $\mathrm{H}_{2}$. Finally, a slight dose rate dependence

* Trademark of Welch Scientific Company. 
for $\mathrm{G}\left(\mathrm{H}_{2}\right)$ was observed. At low dose rates, the dependence vanished, and $\mathrm{G}\left(\mathrm{H}_{2}\right.$ ) based on energy sorbed only by the organic material was 4.6 molecules $/ 100 \mathrm{eV}$ for the octane and 2.0 for the vacuum pump oil.

\section{Results and Discussion}

Radiolytic pressurization at a dose rate of $1.4 \times 10^{7} \mathrm{rads} / \mathrm{hr}$ is shown in Figure 5. Clearly, a steady state pressure was not attained with either n-octane or vacuum pump oil. Gas analysis indicated that the evolved gas was nominally $96 \% \mathrm{H}_{2}, 3 \% \mathrm{CO}_{2}$, and $1 \% \mathrm{CH}_{4}$ in each case. Approximately $50 \%$ of the $\mathrm{O}_{2}$ was consumed in each test, and $\mathrm{N}_{2}$ was unaffected. The $\mathrm{G}$ values for gas production were calculated from Equation $l$ where $M$ is now the mass of.vermiculite and organic material irradiated. Results were 2.1 molecules $/ 100 \mathrm{eV}$ for $\mathrm{n}$-octane and 1.2 for vacuum pump oil. $G$ values for the individual gas components were obtained by multiplying the above $G$ value times the fraction of that gas present.

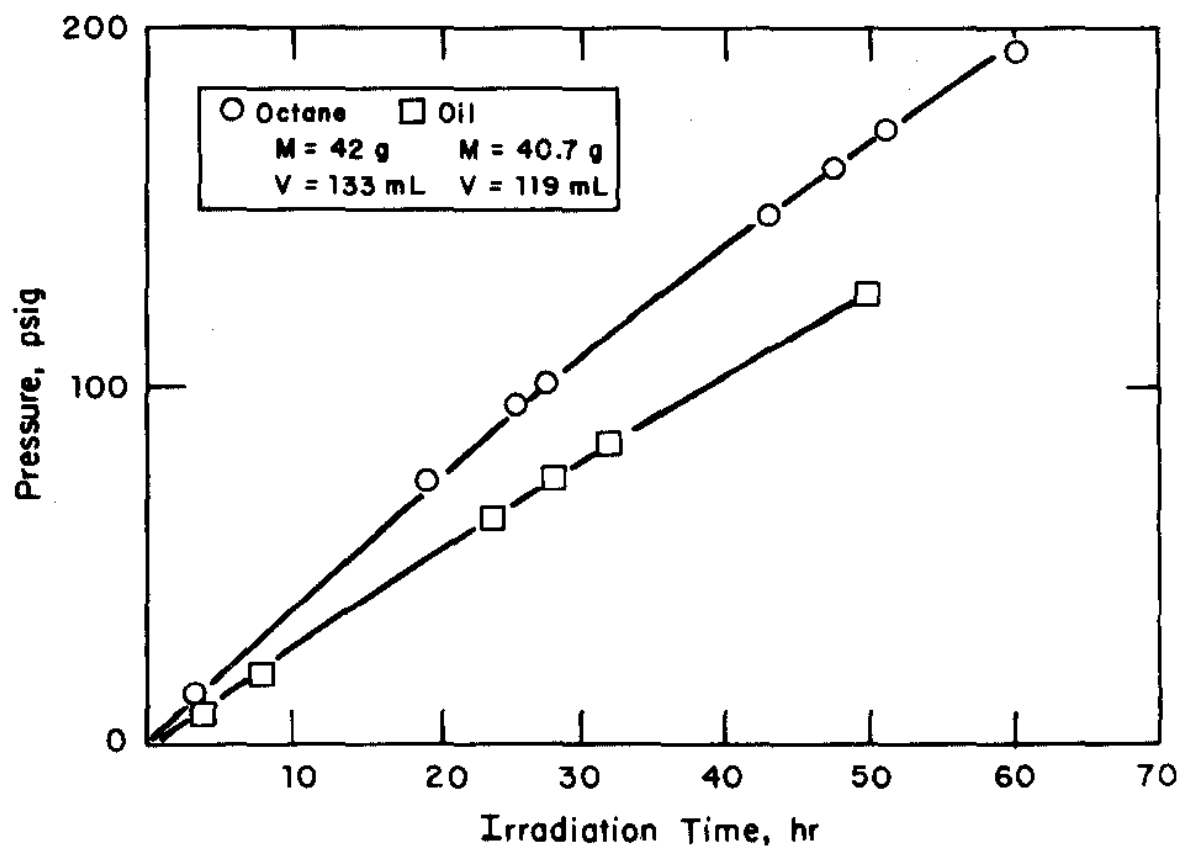

FIGURE 5. Pressurization from Gamma Radiolysis of Organic Material at $31^{\circ} \mathrm{C}$ 
Tests at $1.4 \times 10^{7} \mathrm{rads} / \mathrm{hr}$ determined how the amount of organic material sorbed onto the vermiculite affected $\mathrm{G}\left(\mathrm{H}_{2}\right)$. The results (Figure 6 ) indicated that $\mathrm{G}\left(\mathrm{H}_{2}\right)$ was directly proportional to the amount of organic material present and predicted that radiolysis of dry vermiculite should produce no $\mathrm{H}_{2}$. This prediction was confirmed by irradiating vermiculite containing no organic. The linearity of the data in Figure 6 indicates that energy sorbed by the vermiculite does not cause the organic material to decompose to form $\mathrm{H}_{2}$. Similar results were obtained for the small yields of $\mathrm{CO}_{2}$ and $\mathrm{CH}_{4}$.

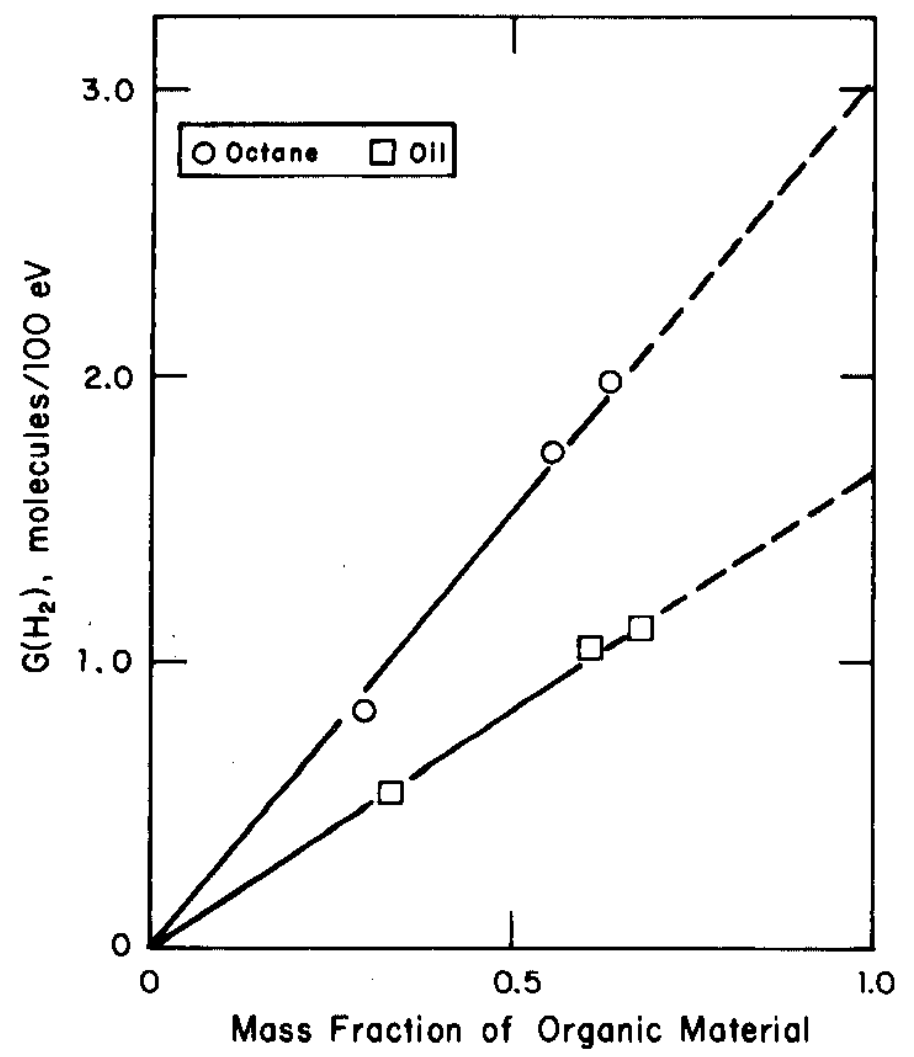

FIGURE 6. Dependence of $G\left(\mathrm{H}_{2}\right)$ on Mass Fraction of Sorbed Organic Material 
To determine the dose rate dependence of $\mathrm{G}\left(\mathrm{H}_{2}\right)$, samples were irradiated at lower dose rates $\left(1.5 \times 10^{5}\right.$ and $4.8 \times 10^{5}$ $\mathrm{rads} / \mathrm{hr}$ ). A typical result is shown in Figure 7 . The initial pressure decrease was due to $\mathrm{O}_{2}$ being consumed faster than $\mathrm{H}_{2}$ was produced. The final gas composition was $23 \% \mathrm{H}_{2}, 73 \% \mathrm{~N}_{2}$, and $4 \% \mathrm{O}_{2}$. Comparison of the partial pressures before and after radiolysis indicated that $\mathrm{N}_{2}$ was unaffected and $\mathrm{O}_{2}$ was $280 \%$ consumed. $\mathrm{G}\left(\mathrm{H}_{2}\right)$ calculated from the final gas composition and total dose to the organic material (not the vermiculite) was 1.9 molecules $/ 100 \mathrm{eV}$. Because $\mathrm{H}_{2}$ was the only gas evolved in significant quantity, $\mathrm{G}\left(\mathrm{H}_{2}\right)$ could al so be calculated from the final positive slope in Figure 7 and the dose rate. The result $(1.8$ molecules $/ 100 \mathrm{eV}$ ) agrees with that calculated from the composition. The dose rate dependence for $\left.\mathrm{G}_{(\mathrm{H}}\right)$ (again based only on the energy sorbed by the organic material) for the oil and for n-octane is shown in Figure 8 . The values at $1.4 \times 10^{7}$ $\mathrm{rads} / \mathrm{hr}$ were obtained by extrapolating the data in Figure 6 to an organic mass fraction of 1.0. At low dose rates, the dose rate dependence of $\mathrm{G}\left(\mathrm{H}_{2}\right)$ vanished for both materials. The value of 4.6 molecules/100 eV for the sorbed n-octane agrees with the value obtained when pure liquid n-octane was irradiated. ${ }^{12}$ This agreement indicates that sorption onto vermiculite does not significantly affect the radiation chemistry of the n-octane. Also, this agreement indicates, as do the data in Figure 6, that energy forming $\mathrm{H}_{2}$ is not being transformed from vermiculite to the organic material.

The $100-\mathrm{eV}$ consumption of $\mathrm{O}_{2}\left[\mathrm{G}\left(-\mathrm{O}_{2}\right)\right]$ was calculated from the data in Figure 7 . The molecules of $\mathrm{O}_{2}$ consumed were calculated from the final gas composition. The dose necessary for this consumption was calculated from the dose rate and the time indicated in Figure 7 where pressure started to increase again. For the data in Figure $7, \mathrm{G}\left(-\mathrm{O}_{2}\right)$ was 5.6 molecules $/ 100 \mathrm{eV}$. In a test with n-octane, $G\left(-\mathrm{O}_{2}\right)$ was 5.0 molecules $/ 100 \mathrm{eV}$. Oxygen is consumed by reaction with radiolytically produced organic radicals on the vermiculite to form peroxides that eventually lead to aldehydes, ketones, or carboxylic acids. Oxygen was not completely consumed because it was apparently unable to diffuse from the pressure gauge, sampling valve, and associated tubing into the radiation field where it could react. In tests with the gauge and valve removed where nearly all the gas volume was in the radiation field, $\sim 95 \%$ of the $\mathrm{O}_{2}$ was consumed.

Another gamma radiolysis test was performed to determine whether a steady state $\mathrm{H}_{2}$ pressure might result after complete $\mathrm{O}_{2}$ consumption. At $1.4 \times 10^{7} \mathrm{rads} / \mathrm{hr}$, an octane vermiculite sample was irradiated in an argon atmosphere. After 64 hours, the $\mathrm{H}_{2}$ pressure was 200 psig and still increasing linearly indicating no approach to a steady state pressure. This pressure increase results from 1 ack of a back reaction removing $\mathrm{H}_{2}$. 


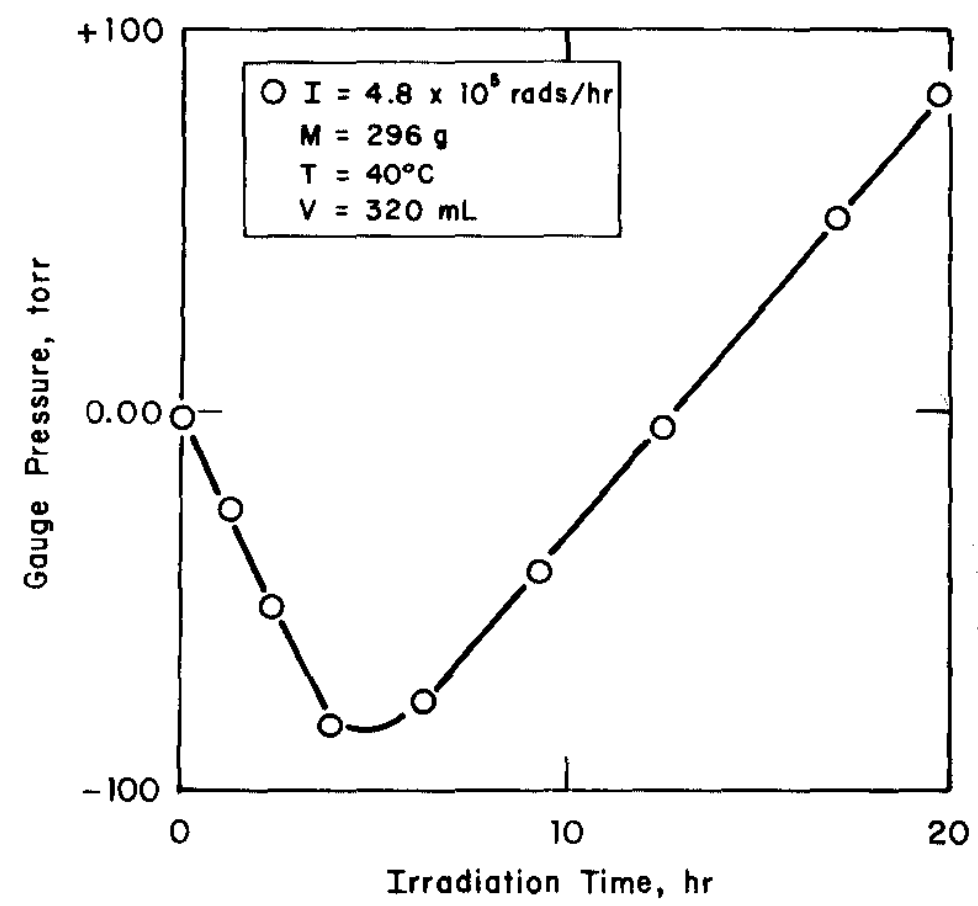

FIGURE 7. Pressurization from Gamma Radiolysis of $0 i 1$ Sorbed onto Vermiculite

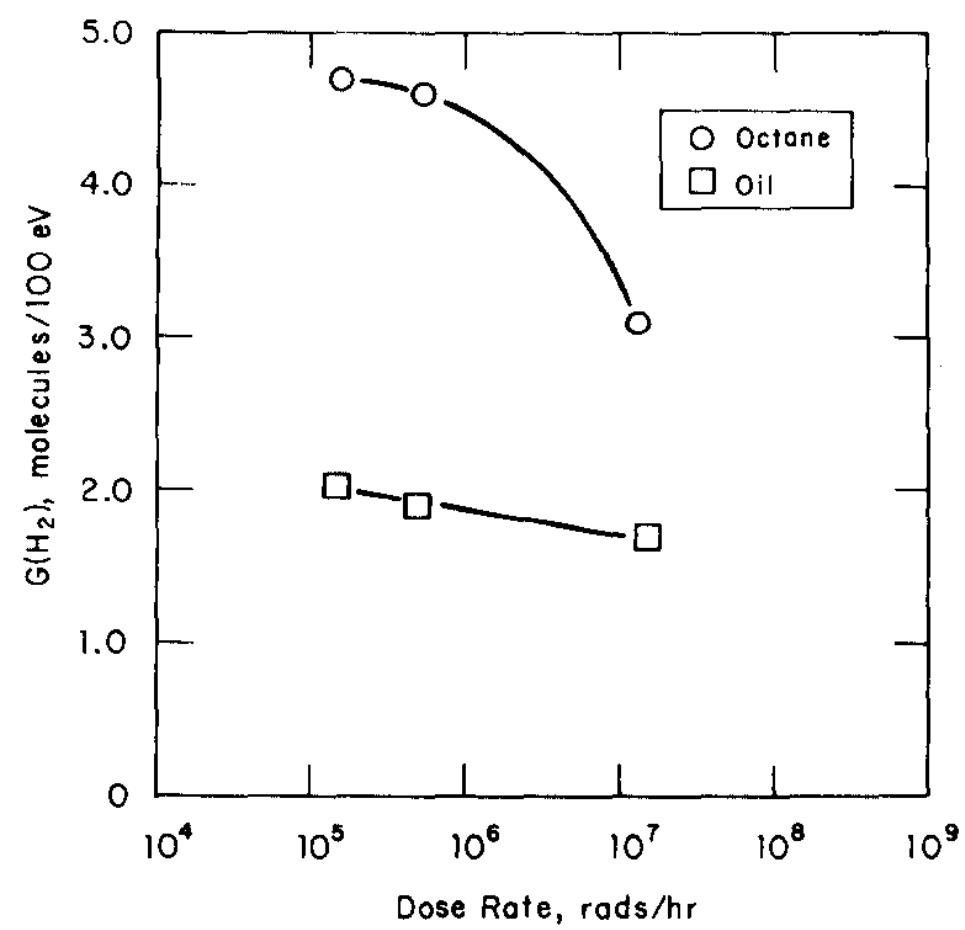

FIGURE 8. Dependence of $G\left(H_{2}\right)$ for Sorbed Organic Material on Gamma Dose Rate 
Generally, the organic radicals $(R \cdot)$ are not energetic enough to react with $\mathrm{H}_{2}$ (Reaction 8 ); thus, a steady state is not attained. ${ }^{13}$

$$
\mathrm{R} \bullet+\mathrm{H}_{2} \rightarrow \mathrm{RH}+\mathrm{H}
$$

This test is in contrast to water radiolysis where a steady state is attained because of the reaction between $\mathrm{OH}$ and $\mathrm{H}_{2}$.

\section{Experimental Procedures}

For the tests at $1.4 \times 10^{7} \mathrm{rads} / \mathrm{hr}$ with the submerged ${ }^{60} \mathrm{Co}$ source, samples were irradiated in steel test tubes $20-\mathrm{cm} 1$ ong by $2.8-\mathrm{cm}$ ID. Approximately $40 \mathrm{~g}$ of the mixture $(2 \mathrm{~g}$ organic/g vermiculite) was placed in the tube, and the tube was sealed to a pressure gauge and sampling valve by $\sim 25 \mathrm{ft}$ of $0.1-\mathrm{cm}-\mathrm{ID}$ tubing. To decrease the volatilization of n-octane because of gamma heating during radiolysis, the tube was enclosed by coils for water cooling. For the tests with the ${ }^{6}{ }^{\circ} \mathrm{Co}$ Garmace 22 220, $2300-\mathrm{g}$ samples were irradiated in $500-\mathrm{cc}$ bottles as with the concrete radiolysis tests. Dosimetry was performed with thin-film dosimeters ${ }^{8}$ or with the Fricke dosimeter. ${ }^{9}$ A11 other procedures were identical to those described for the concrete radiolysis tests.

\section{Alpha Radiolysis Tests}

Alpha radiolysis tests indicated that, as with gamma radiolysis, $\mathrm{H}_{2}$ was the most significant product. Traces of $\mathrm{CH}_{4}$ were al so produced, and $\mathrm{O}_{2}$ was consumed. For n-octane, $\mathrm{G}\left(\mathrm{H}_{2}\right)$ was 4.2 molecules $/ 100 \mathrm{eV}$, nearly equal to the value found for gamma radiolysis (4.6). For the pump oil, $\mathrm{G}\left(\mathrm{H}_{2}\right)$ was 2.7 , slightly higher than that obtained for gamma radiolysis (2.0).

\section{Results and Discussion}

Radiolytic pressure increases for two tests with n-octane containing 7.2 and $4.3 \mathrm{mg}$ of $244 \mathrm{Cm}$ are shown in Figure 9. At the end of the tests, gas composition for each was nominally $60 \%$ $\mathrm{H}_{2}, 25 \% \mathrm{~N}_{2}, 3 \% \mathrm{CH}_{4}$, and $2 \% \mathrm{O}_{2}$. Comparison of the partial pressures before and after radiolysis indicates that $\mathrm{N}_{2}$ was unaffected and $\mathrm{O}_{2}$ was $90 \%$ consumed. $\mathrm{G}\left(\mathrm{H}_{2}\right)$ values were calculated from the slopes in Figure 9 , the dose rate (calculated from the amount of . ${ }^{4} \mathrm{C} . \mathrm{i}$ present), and the volume of gas produced. Based on energy sorbed by the organic material, $\mathrm{G}\left(\mathrm{H}_{2}\right)$ was 4.2 molecules/100 eV for the higher dose rate, and 4.3 for the lower, indicating no dose rate effect. Alpha radiolysis of the vacuum pump oil was 


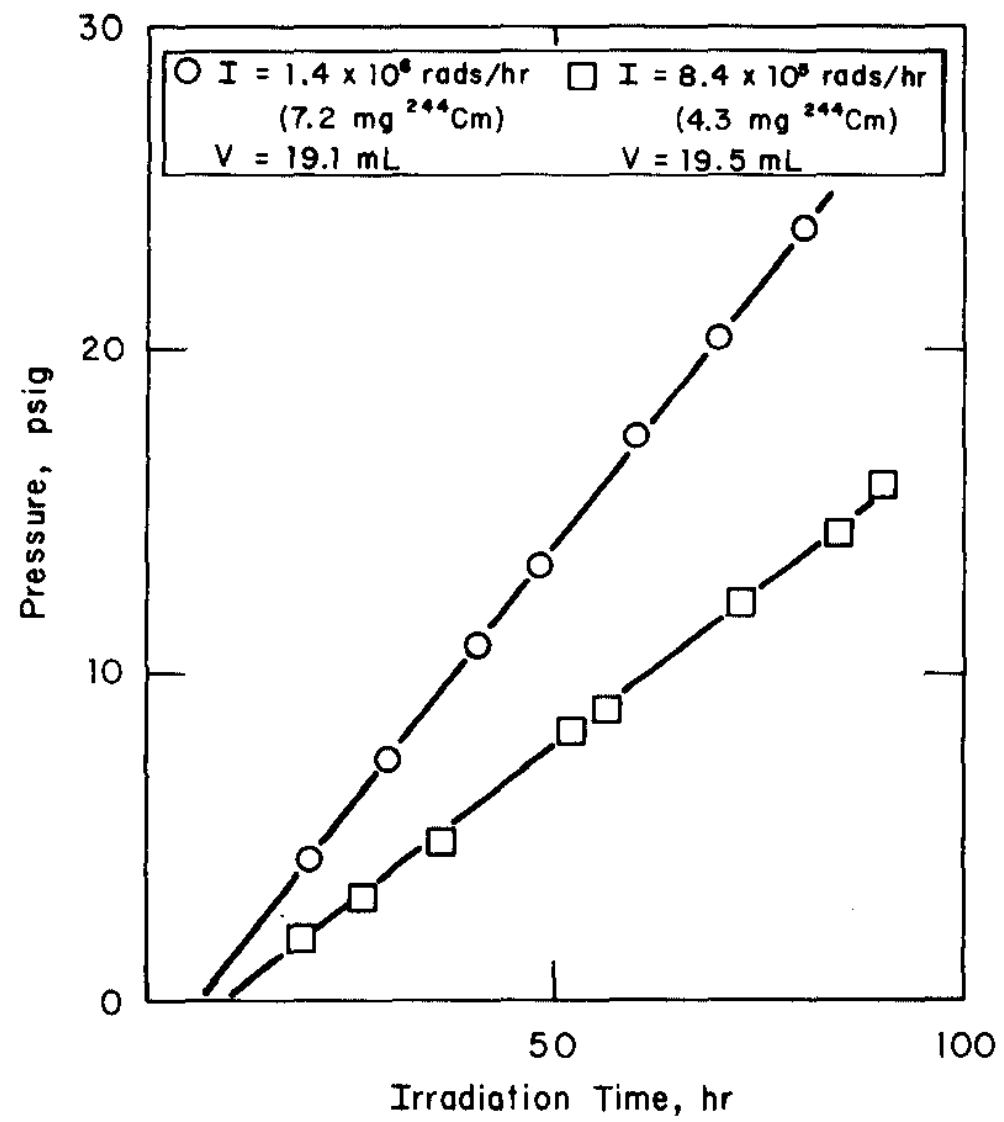

FIGURE 9. Pressurization from Alpha Radiolysis of Octane Sorbed onto VermicuTite at $23^{\circ} \mathrm{C}$

studied at only one dose rate (Figure 10). Gas composition at the end of the test was $73 \% \mathrm{H}_{2}, 25 \% \mathrm{~N}_{2}, 1 \% \mathrm{CH}_{4}$, and $0.7 \% \mathrm{O}_{2} . \mathrm{O}_{2}$ was $94 \%$ consumed, and $\mathrm{N}_{2}$ was not affected by radiolysis. $\mathrm{G}\left(\mathrm{H}_{2}\right)$ was 2.7 molecules/eV.

\section{Experimental Procedures}

The irradiation containers were identical to those used in alpha radiolysis tests of the concrete samples (page 10). In these tests, $2.9 \mathrm{~g}$ of organic material was sorbed onto $2.3 \mathrm{~g}$ of vermiculite. A known amount of ${ }^{244} \mathrm{Cm}$ in an aqueous solution was sorbed onto the vermiculite. The water was then removed by heating the mixture to a constant weight. The organic material was then added, and the mixture was sealed in the steel tube with a pressure gauge and sampling valve. After the test, the gas was sampled and analyzed as in the concrete alpha radiolysis tests. 


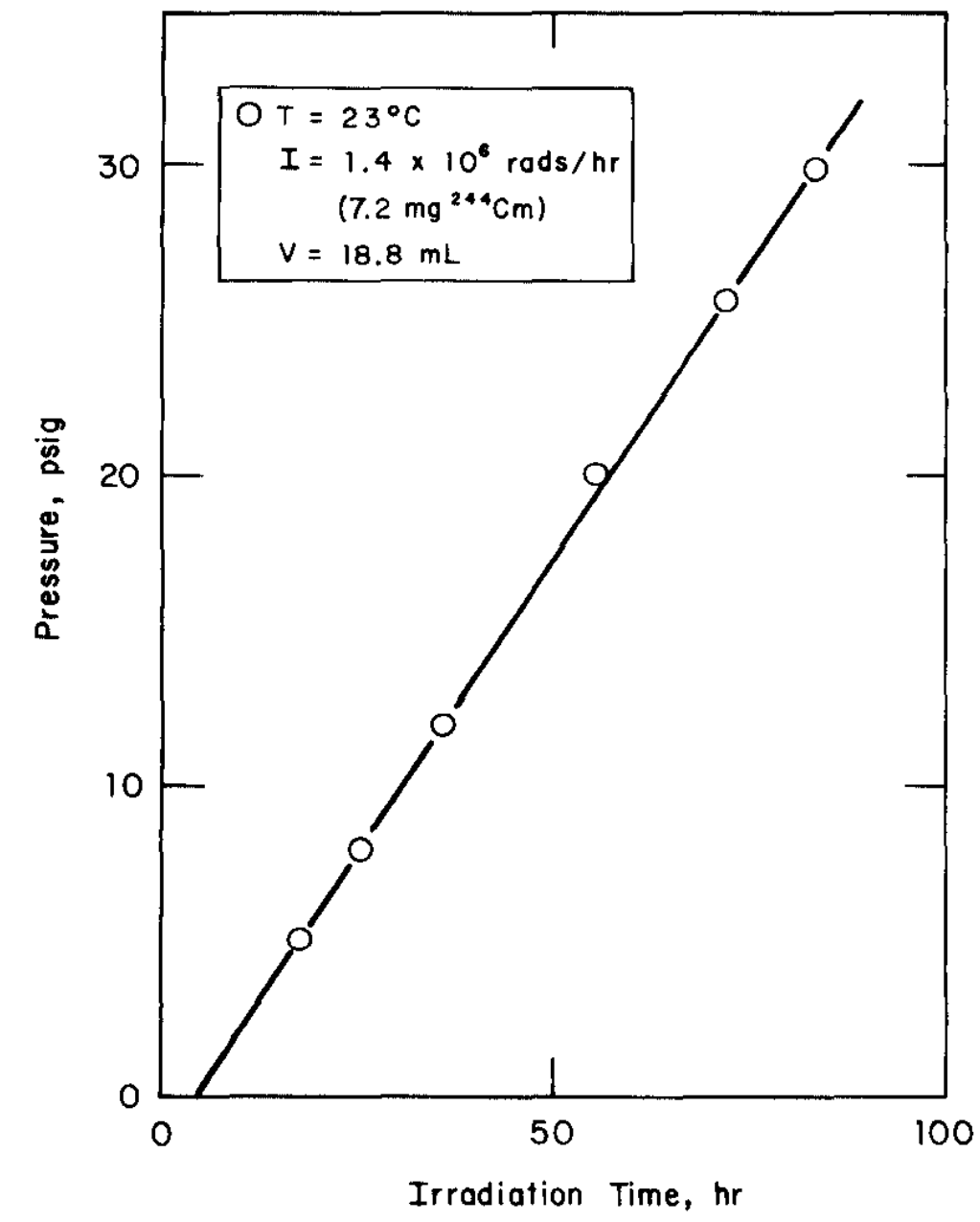

FIGURE 10. Pressurization from Alpha Radiolysis of Vacuum Pump 0i] Sorbed onto Vermiculite 
$\mathrm{G}\left(\mathrm{H}_{2}\right)$ for ${ }^{3} \mathrm{H}$ beta radiolysis can be estimated from the $\mathrm{G}\left(\mathrm{H}_{2}\right)$ values for alpha and gamma radiolysis. Radiolytic products formed by the three types of radiation are expected to be identical because all three transfer energy to electrons of the material irradiated. These energetic electrons then cause chemical degradation to the material. Because of the different LET values of the radiations, products may be formed with different $100-\mathrm{eV}$ yields. For example, with the concrete, $\mathrm{G}_{\left(\mathrm{H}_{2}\right)}$ was 0.03 molecule/ $100 \mathrm{eV}$ for gamma radiolysis and 0.6 for alpha radiolysis. Similarly, for liquid water, $G\left(\mathrm{H}_{2}\right)$ is 0.5 for gamma radiolysis and 1.6 for alpha radiolysis. ${ }^{3}$ This difference results from different spatial distribution of intermediates formed by the radiations. In water, LET values for ${ }^{60} \mathrm{Co}$ gamma, ${ }^{3} \mathrm{H}$ beta, and ${ }^{244} \mathrm{Cm}$ alpha radiations are $0.02,0.36$, and $8.8 \mathrm{eV} / \mathrm{A}^{\circ}$, respectively. ${ }^{5}$ Although these parameters have not been determined in concrete or vermiculite, their relative values, $1.0,18$, and 440 are probably reasonably invariant from system to system. Therefore, $\mathrm{G}\left(\mathrm{H}_{2}\right)$ for ${ }^{3} \mathrm{H}$ beta radiolysis was estimated for each waste form from plots of $\mathrm{G}\left(\mathrm{H}_{2}\right)$ versus relative LET values.

\section{$G\left(\mathrm{H}_{2}\right)$ for Concrete Waste}

In Figure 11, the two values for $\mathrm{G}_{\left(\mathrm{H}_{2}\right)}$ for concrete radiolysis are plotted along with data for $\left.\mathrm{G}_{(\mathrm{H}}\right)$ from 1 iquid water for comparison. The dashed line is a linear interpolation of the concrete data and suggests that $\mathrm{G}\left(\mathrm{H}_{2}\right)$ for ${ }^{3} \mathrm{H}$-beta radiolysis is 0.3 molecule/ $100 \mathrm{eV}$. By following the curvature of the data for liquid water, n0.1 is estimated. This estimate may be closer to the true value because $\mathrm{H}_{2}$ is probably formed in the two systems by the same mechanism (recombination of $\mathrm{H}$ atoms). However, until radiolysis experiments are performed with ${ }^{3} \mathrm{H}$ beta rays, the estimate for $\left.\mathrm{G}_{(\mathrm{H}}\right)$ has to be 0.1 to 0.3 molecule $/ 100 \mathrm{eV}$.

\section{$G\left(\mathrm{H}_{2}\right)$ for Solidified Organic Waste}

The effect of LET on $\mathrm{G}\left(\mathrm{H}_{2}\right)$ is much less in radiolysis of the organic materials sorbed onto vermiculite (Figure 12). The values for ${ }^{60} \mathrm{Co}$ gamma radiolysis were calculated at the low dose rates. Because of this smaller effect of LET, values for ${ }^{3} \mathrm{H}$ beta radiolysis can be estimated more accurately. For the n-octane, 4.4 molecules/100 eV is estimated; for the vacuum pump oil, 2.2 is estimated. These values were used to estimate radiolytic pressurization of containers of tritiated waste. 


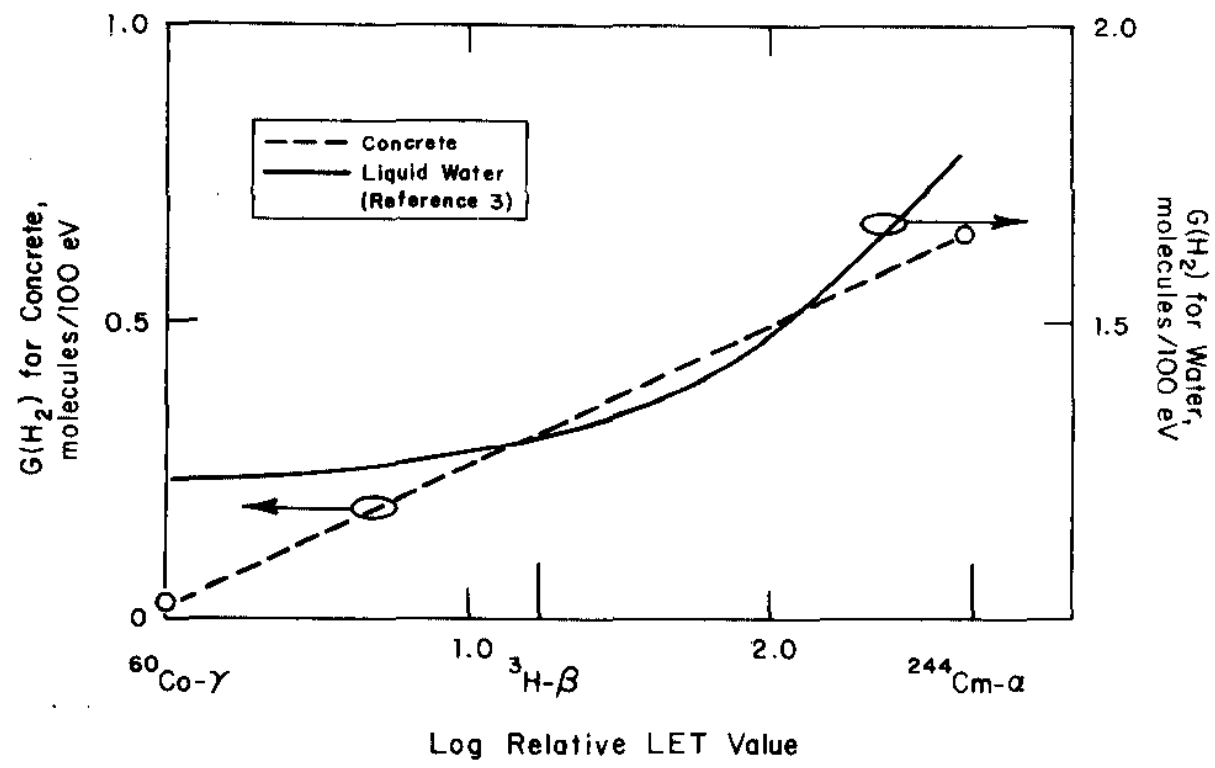

FIGURE 11. Effect of Linear Energy Transfer on $G\left(\mathrm{H}_{2}\right)$ from Radiolysis of Concrete and Liquid Water

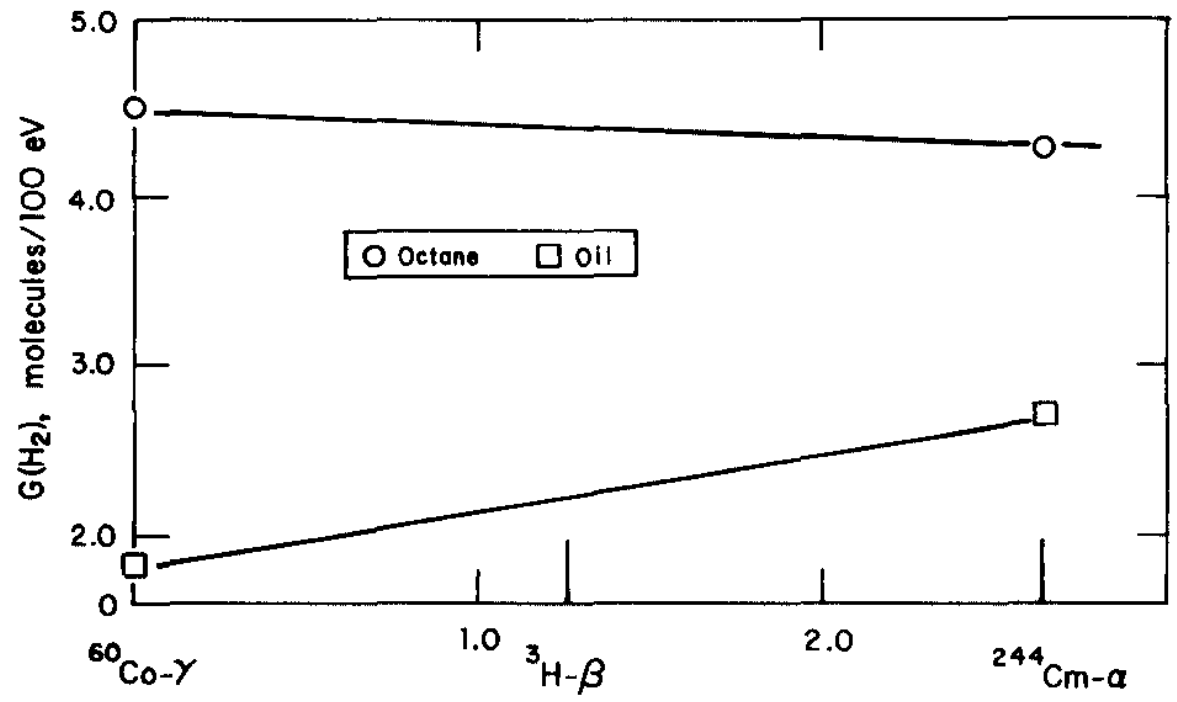

Log Relative LET Value

FIGURE 12. Effect of Linear Energy Transfer on $G\left(\mathrm{H}_{2}\right)$ from Radiolysis of Octane or Vacuum Pump 0il Sorbed onto Vermiculite 


\section{RADIOLYTIC PRESSURIZATION IN TRITIATED WASTE CONTAINERS}

For long-term storage of tritium waste, the solidified material is sealed in an appropriate primary container such as a metal or polyethylene drum. I This drum is then sealed in a metal drum that is, in some cases, sealed in another metal drum. From results of this study, pressurization rates and pressures in the primary drums can be estimated as a function of storage time if the tritium content and gas volume in the drums are known.

\section{Pressurization from Tritiated Concrete Waste}

Because of $\mathrm{H}_{2}$ production, containers of tritiated concrete will pressurize. However, because of $\mathrm{O}_{2}$ depletion, the rate of total pressurization will be less than that of $\mathrm{H}_{2}$ pressurization alone. Initially, the $\mathrm{H}_{2}$ pressurization rate is linear and is given by

$$
\frac{\mathrm{dP}_{\mathrm{H}_{2}}}{\mathrm{dT}}=\frac{\mathrm{RT}}{\mathrm{NV}} \cdot \frac{\mathrm{G}\left(\mathrm{H}_{2}\right)}{100} \cdot \frac{\mathrm{dE}}{\mathrm{dt}}
$$

where

$$
\begin{aligned}
\mathrm{R} & =\text { gas constant, psi liter/mole }{ }^{\circ} \mathrm{K} \\
\mathrm{T} & =\text { temperature, }{ }^{\circ} \mathrm{K} \\
\mathrm{N} & =\text { Avogadro's number, molecules/mole } \\
\mathrm{V} & =\text { gas volume in the container } \\
\mathrm{G}\left(\mathrm{H}_{2}\right) & =0.1 \text { to } 0.3 \text { molecule } / 100 \mathrm{eV} \\
\frac{\mathrm{dE}}{\mathrm{dt}} & =\text { dose rate from }{ }^{3} \mathrm{H} \text { beta decay, eV/day }
\end{aligned}
$$

The dose rate is given by

$$
\frac{\mathrm{dE}}{\mathrm{dt}}=\frac{3.7 \times 10^{10} \mathrm{dis}}{\mathrm{sec} \mathrm{Ci}} \cdot \frac{8.6 \times 10^{4} \mathrm{sec}}{\mathrm{day}} \cdot \mathrm{Ci}_{\mathrm{t}} \cdot \overline{\mathrm{E}}
$$

where

$$
\begin{aligned}
C i_{t} & =\text { curies of }{ }^{3} \mathrm{H} \text { present } \\
\overline{\mathrm{E}} & =\text { average energy per beta particle, } 5.69 \mathrm{keV}^{14}
\end{aligned}
$$


Because of the radioactive decay of ${ }^{3} \mathrm{H}, \mathrm{Ci} i_{t}=\mathrm{Ci}_{t}{ }^{\circ} \mathrm{e}^{-\lambda \mathrm{t}}$ where $\mathrm{Ci}_{t}{ }^{\circ}$ is the initial amount of ${ }^{3} \mathrm{H}$ present and $\lambda$ is its decay constant $\left(1.5 \times 10^{-4} \mathrm{day}^{-1}\right){ }^{15}$ Equation 9 then becomes

$$
-\frac{\mathrm{dP}_{2}}{\mathrm{dt}}=\frac{\mathrm{RT}}{\mathrm{NV}} \cdot \frac{\mathrm{G}\left(\mathrm{H}_{2}\right)}{100} \cdot \frac{1.8 \times 10^{19} \mathrm{eV}}{\mathrm{Ci} \cdot \mathrm{day}} \cdot \mathrm{Ci}_{\mathrm{t}}{ }^{\circ} \mathrm{e}^{-\lambda \mathrm{t}}
$$

Integrating Equation 11 gives $\mathrm{P}_{\mathrm{H}_{2}}$ as a function of time

$$
\mathrm{P}_{\mathrm{H}_{2}}=\frac{\mathrm{RT}}{\mathrm{NV}} \cdot \frac{\mathrm{G}\left(\mathrm{H}_{2}\right)}{100} \cdot \frac{1.8 \times 10^{19} \mathrm{eV}}{\mathrm{Ci}_{t} \text { day }} \cdot \frac{\mathrm{Ci}_{t^{\circ}}}{\lambda} \cdot\left(1-\mathrm{e}^{-\lambda t}\right)
$$

As the $\mathrm{H}_{2}$ pressure increases in the container, the rate of $\mathrm{H}_{2}$ pressurization decreases. This pressure decrease has been established for ${ }^{3} \mathrm{H}$ beta radiolysis by data obtained at another $1 \mathrm{ab}-$ oratory* where a sample of solidified aqueous waste (tritiated water sorbed onto vermiculite) was sealed in a steel container. The pressure in the container initially increased, but eventually attained a steady state (Figure 13). At steady state, the $\mathrm{H}_{2}$ pressure based on gas composition was $11 \mathrm{psi}$. The remainder of the gas was $\mathrm{N}_{2}$ and $\mathrm{O}_{2}$ along with traces of $\mathrm{He}$ and $\mathrm{D}_{2}$. The dose rate in the waste $\left(9 \times 10^{4} \mathrm{rads} / \mathrm{hr}\right)$ was estimated from the tritium content of the waste $\left(1.7 \times 10^{5} \mathrm{Ci}\right)$ and its mass $(14 \mathrm{~kg}$ water on $\imath_{8} \mathrm{~kg}$ vermiculite). ${ }^{16}$ When a similar mixture of water and vermiculite was gamma-irradiated at this dose rate at SRP, the steady state $\mathrm{H}_{2}$ pressure was $9 \pm 2 \mathrm{psi}$, in reasonable agreement with that obtained by ${ }^{3} \mathrm{H}$ beta radiolysis. This agreement indicates that ${ }^{3} \mathrm{H}$ beta radiolysis effects can be simulated by ${ }^{60} \mathrm{Co}$ gamma radiolysis and that the steady state $\mathrm{H}_{2}$ pressure in waste containers can be estimated from Figure 2 , if the dose rate to the waste is known. At $9 \times 10^{4} \mathrm{rads} / \mathrm{hr}$, a steady state pressure of 14 psi predicted for the concrete is reasonably close to the 11 psi calculated for the water-vermiculite mixture. This agreement suggests that aqueous concrete and vermiculite waste have nearly equal steady state pressures and is to be expected if the oxide solidification matrices do not affect the radiation chemistry of $\mathrm{H}_{2} \mathrm{O}$ significantly.

The amount of pressurization in a conceptual waste container will now be estimated. The assumed container is a 27-gallon drum containing $10^{5} \mathrm{Ci}$ of tritium solidified in 20 gallons of concrete. The void volume is 7.1 gallons (27 liters) if the concrete is assumed to have a $10 \%$ porosity. The initial $\mathrm{H}_{2}$ pressurization

* Letter from D. R. Storey, Monsanto Research Corporation, Miamisburg, Ohio, to R. L. Wainwright, USAEC, Miamisburg, Ohio, June 24,1974 . 


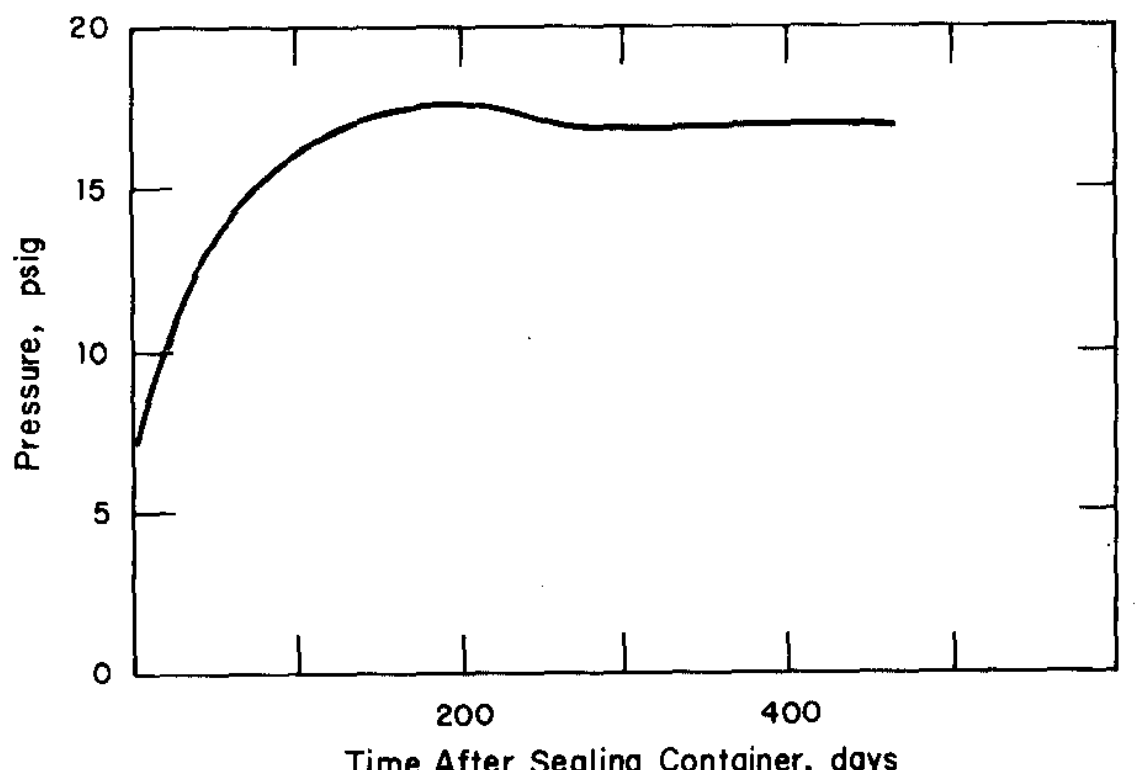

FIGURE 13. Pressurization from ${ }^{3} \mathrm{H}-\mathrm{B}$ Radiolysis of Water Sorbed onto Vermiculite (Data obtained from D. R. Storey, Monsanto Research Corporation, Miamisburg, Ohio, June 24, 1974)

rate at $23^{\circ} \mathrm{C}$ calculated from Equation 11 is 0.04 to $0.12 \mathrm{psi} / \mathrm{day}$ depending on the choice for $\left.\mathrm{G}_{(\mathrm{H}}\right)(0.1$ or 0.3 molecule $/ 100 \mathrm{eV})$. At these rates, the gaseous mixture will become flammable $(0.4 \%$ $\mathrm{H}_{2}$ or $\left.0.6 \mathrm{psi} \mathrm{H}_{2}\right)^{17}$ in approximately 6 to 15 days assuming no $\mathrm{O}_{2}$ depletion. Because of this depletion, however, longer times will be necessary. In this container, the dose rate is $1.6 \times 10^{4}$ $\mathrm{rads} / \mathrm{hr}$ if a density of $1 \mathrm{~kg} / \mathrm{L}$ is assumed for the concrete. From Figure 2, a steady state $\mathrm{H}_{2}$ pressure of $<10 \mathrm{psi}$ is predicted.

Pressurization from Tritiated Organic Waste

$\mathrm{H}_{2}$ pressurization rates from n-octane or vacuum pump oil sorbed on vermiculite are given by

$$
\frac{\mathrm{dP}_{\mathrm{H}_{2}}}{\mathrm{dt}}=\frac{\mathrm{RT}}{\mathrm{NV}} \cdot \frac{\mathrm{G}\left(\mathrm{H}_{2}\right)}{100} \cdot \frac{\mathrm{dE}}{\mathrm{dt}} \cdot \mathrm{X}
$$

$X$ is the mass fraction of organic material present, and $\left.\mathrm{G}_{(\mathrm{H}}\right)$ is based on $100-e V$ energy sorbed by the organic material. The term $(\mathrm{dE} / \mathrm{dt}) \mathrm{X}$ is the dose rate to the organic material. A better estimate of this dose rate would be based on the electron fraction of organic material because alpha, beta, and gamma radiations primarily transfer energy to the electrons of a system. ${ }^{18}$ Using 
the mass fraction introduces an error of $<10 \%$ that is considered not significant in these pressure estimations. Relating $\mathrm{dE} / \mathrm{dt}$ to the initial curies of ${ }^{3} \mathrm{H}$ present and integrating Equation 11 give

$$
\mathrm{P}_{\mathrm{H}_{2}}=\frac{\mathrm{RT}}{\mathrm{NV}} \cdot \frac{\mathrm{G}\left(\mathrm{H}_{2}\right) \mathrm{X}}{100} \cdot \frac{\mathrm{Ci}_{\mathrm{t}}{ }^{\circ} \cdot \mathrm{I}}{\lambda}\left(1-\mathrm{e}^{-\lambda \mathrm{t}}\right)
$$

where

$$
\mathrm{I}=1.8 \times 10^{19} \mathrm{eV} / \mathrm{Ci} \cdot \mathrm{day}
$$

Both the gamma and alpha radiolysis data indicate that a significant back reaction for $\mathrm{H}_{2}$ does not occur with the organic material. This indicates that Equation 14 may be valid as 1 ong as organic material and ${ }^{3} \mathrm{H}$ are present. On this basis, the pressure of $\mathrm{H}_{2}$ after decay of all the ${ }^{3} \mathrm{H}$ has decayed is given by

$$
\mathrm{P}_{\mathrm{H}_{2}}\left(\text { fina1) }=\frac{\mathrm{RT}}{\mathrm{NV}} \cdot \frac{\mathrm{G}\left(\mathrm{H}_{2}\right) \mathrm{X}}{100} \cdot \frac{\mathrm{Ci}_{\mathrm{t}} \cdot \mathrm{I}}{\lambda}\right.
$$

The pressure of $\mathrm{O}_{2}$ as a function of time is given by

$$
\mathrm{P}_{\mathrm{O}_{2}}=\mathrm{P}_{\mathrm{O}_{2}}^{\circ}-\frac{\mathrm{RT}}{\mathrm{NV}} \cdot \frac{\mathrm{G}\left(-\mathrm{O}_{2}\right) \mathrm{X}}{100} \cdot \frac{\mathrm{Ci}_{\mathrm{t}} \cdot \mathrm{I}}{\lambda} \cdot\left(1-\mathrm{e}^{-\lambda \mathrm{t}}\right)
$$

where $\mathrm{P}_{0}^{\circ}$ is nominally 3 psi. The gamma and alpha radiolysis data indicate that eventually $\mathrm{O}_{2}$ will be essentially depleted from the gas phase. $\mathrm{CH}_{4}$ and $\mathrm{CO}_{2}$ will al so be produced, but their contribution to the total pressure will be negligible.

The pressurization from tritiated organic solvent sorbed onto vermiculite in a conceptual waste container will now be estimated. The container is a 27 -gallon drum containing $10^{4}$ Ci of tritium in 7.4 gallons of octane or vacuum pump oil sorbed onto 20 gallons of vermiculite. With $0.7 \mathrm{~g} / \mathrm{mL}$ as the density of the organic material and 0.15 as the bulk density of vermiculite (estimated at SRL), the radiation dose rate is $5400 \mathrm{rads} / \mathrm{hr}$. The mass fraction organic material is 0.64 and the void volume is 69 liters (with $2.3 \mathrm{~g} / \mathrm{mL}$ as the crystal density of the vermiculite). $\mathrm{G}\left(\mathrm{H}_{2}\right)$ values for octane and pump oil are 4.4 and 2.2 molecules $/ 100 \mathrm{eV}$, respectively (Figure 12). The initial pressurization rates are 0.044 and $0.02 \mathrm{psi} /$ day, respectively, for octane and pump oil. If no depletion in $\mathrm{O}_{2}$ is assumed, the mixtures become flammable in 14 and 7 days, respectively. With $\mathrm{O}_{2}$ depletion, these times become longer. Eventually, the $\mathrm{O}_{2}$ will be essentially all consumed. The final pressures of $\mathrm{H}_{2}$ for the two materials are $310 \mathrm{psi}$ for the octane and $155 \mathrm{psi}$ for the vacuum pump oil. With larger amounts of tritium, larger final pressures would be generated. 
1. T. B. Rhinehammer and E. A. Mershad. "Techniques and Facilities for Handling and Packaging Tritiated Liquid Wastes for Burial." p 1067 in Proceedings of the Second $A E C$ Environmental Protection Conference, Albuquerque, NM, Apriz 16, 1974. USAEC Report WASH-1332(74)(Vo1. 2) (1974).

2. J. A. Franz and L. L. Burger. Polymeric Media for Tritium Fixation. USERDA Report BNWL-B-430, Battelle Pacific Northwest Laboratories, Richland, WA (1975).

3. I. G. Draganić and Z. D. Draganić. The Radiation Chemistry of Water. Academic Press, New York, NY (1971).

4. A. J. Swallow. Radiation Chemistry of Organic Compounds. Pergamon Press, New York, NY (1960).

5. E. J. Henley and E. R. Johnson. The Chemistry and Physics of High Energy Reactions. p 254, University Press, Washington, DC (1969).

6. N. E. Bibler. Radiolytic Gas Production from Conorete Containing Savannah River Plant Waste. USERDA Report DP-1464, Savannah River Laboratory, E. I. du Pont de Nemours and Company, Aiken, SC (to be issued).

7. W. G. Burns and R. Barker. "Dose Rate and Linear Energy Transfer Effects in Radiation Chemistry." p 305 in Progress in Reaction Kinetics, Vol. 3, Pergamon Press, New York, NY (1965).

8. N. E. Bibler. Calibration of Intense ${ }^{60}$ Co Garma Ray Sources at the Savannah River Plant. USERDA Report DP-1414, Savannah River Laboratory, E. I. du Pont de Nemours and Company, Aiken SC (1976)

9. H. Fricke and E. J. Hart. $\mathrm{p} 185$ in Radiation Dosimetry, Vol. 2 (2nd Edition). F. H. Attix and W. C. Roesch, editors. p 185, Academic Press, NY (1966).

10. C. Kellar. The Chemistry of the Transuranium Elements. p 530, Verlag Chemie GmbG, Weinheim, West Germany (1971). 
11. N. E. Bibler. "Curium-244 $\alpha$ Radiolysis of Nitric Acid. Oxygen Production from Direct Radiolysis of Nitrate Ions." J. Phys. Chem. 78, 211 (1974).

12. H. A. Dewhurst. "Radiation Chemistry of Organic Compounds. I. n-Alkane Liquids." J. Phys. Chem. 61, 1466 (1957).

13. J. W. T. Spinks and R. J. Woods. An Introduction to Radiation Chemistry (2nd edition). p 360, John Wiley and Sons, New York, NY (1976).

14. W. L. Pillinger, J. J. Hentges, and J. A. B1air. "Tritium Decay Energy." Phys. Rev. 121, 232 (1961).

15. K. C. Jordan, B. C. Blanke, and W. A. Dudley. "Half-Life of Tritium." J. Inorg. Nucl. Chem. 29, 2129 (1967).

16. J. W. T. Spinks and R. J. Woods. An Introduction to Radiation Chemistry (2nd edition). p 115, John Wiley and Sons, New York, NY (1976).

17. H. F. Coward and G. W. Jones. "Limits of Flammability of Gases and Vapors." p 15 in Buzletin 503, Bureau of Mines. U. S. Government Printing Office, Washington, DC (1952).

18. R. C. Weast (editor-in-chief). Handbook of Chemistry and Physics (51st edition). p B-197, The Chemical Rubber Company, Cleveland, OH (1971). 